\title{
Effect of transgenic insect-resistant maize to the community structure of soil nematodes in two field trials
}

\author{
A. ČEREVKOVÁ1, L'. CAGÁŇ² \\ 1Institute of Parasitology, Slovak Academy of Science, Košice, Slovakia, E-mail: cerev@saske.sk; \\ 2Department of Plant Protection, Slovak Agricultural University, Nitra, Slovakia
}

\begin{abstract}
Article info
Received September 8, 2014 Accepted October 22, 2014
\end{abstract}

\begin{abstract}
Summary
The aim of this study was to determine the effects of Bt maize hybrid cultivation on soil nematode communities in two field trials, as well as to analyse other factors (fertilisation and moisture) responsible for the community structure of soil nematodes. Nematode communities were studied in maize plots at the locality of Borovce in western Slovakia. During 2012 and 2013, hybrids DK440 and DKC3871 (conventional) or DKC4442YG and DKC3872YG (Bt maize, event MON810) were sown in 10 repetitions each. Nematodes were extracted from soil samples collected the maize flowering (July 11, 2012 and July 30, 2013). Altogether, 39 nematode species belonged to 35 genera were identified in two maize variants. The dominant taxa in both variants were Acrobeloides nanus, $\mathrm{Ce}$ phalobus persegnis, Aphelenchoides composticola, Aphelenchus avenae, Eudorylaimus carteri and Filenchus vulgaris. Calculation of the maturity index, plant parasitic index, enrichment index and structure index did not confirm any clear influence of year or hybrid type on soil nematode communities. The proportional representation of $c p-1, c p-2$ and $c p-3-5$ groups of nematode fauna indicated conditions of low stability and high stress. Faunal profiles representing the structure and enrichment conditions of the soil food web showed an environment with a high $\mathrm{C}: \mathrm{N}$ ratio and high levels of fungal feeders. Based on the calculation of the metabolic footprint of nematodes in the soil food web, a difference between the isoline maize variant and Bt maize variant in 2012 was found, but this difference was not readily apparent in 2013. The occurrence of nematodes, their abundance, proportion of feeding types and selected ecological indices did not depend on the type of maize hybrid (Bt or nonBt). Thus, the cultivation of genetically modified maize did not directly influence nematode populations. The application of fertiliser at certain periods does not influence the nematode community. The observed significant higher abundance of nematodes was correlated with soil moisture.
\end{abstract}

Keywords: Bt maize; Nematoda; diversity; Cry1Ab

\section{Introduction}

Nematodes are key agents in important soil processes such as decomposition, mineralisation and nutrient cycling. Alteration of the nematode community structure may have a considerable influence on ecosystem functioning (Bakonyi et al., 2007). They are widespread and highly diverse, occupying multiple trophic positions in soil food web, and they are frequently used as indicators of environmental soil changes (Neher, 2001; Ferris \& Bongers, 2006; Sun et al., 2013). Furthermore, they can provide useful information on soil food web dynamics (DuPont et al., 2009).

In general, previous studies showed that numbers of soil mites
(Prostigmata, Mesostigmata and Oribatei), Collembola and nematodes were similar in soil planted with $\mathrm{Bt}$ maize and soil planted with its isoline (Al-Deeb et al., 2003). The effects of Bt on soil nematodes were relatively small compared to the effects of soil type, plant growth stage and insecticide application (Griffiths et al., 2006). It was also found, that isoline with insecticide had greater non-target effects on nematode communities than the coleopteran-active Bt maize hybrid (Neher et al., 2014). Nematode communities in maize crops may be influenced by many different factors, including crop species, plant age and environmental variables (Karuri et al., 2013).

Non-target organisms, such as soil nematodes, may be exposed to the Cry proteins. Wei et al. (2003) demonstrated that Cry5B, 
Cry14A, Cry21A and Cry6A were toxic to four bacterial-feeding nematode species. Al-Deeb et al. (2003) and Höss et al. (2011) found no effect of Cry3Bb1 in Bt maize on Caenorhabditis elegans. Later, it was found that three insecticidal Cry proteins showed dose-dependent inhibitory effects on Caenorhabditis elegans reproduction (EC50: $0.12-0.38 \mu \mathrm{mol} \mathrm{L}^{-1}$ ), at concentrations that were far above the expected soil concentrations (Höss et al., 2013).

Results concerning the effects of Bt maize on nematodes are conflicting: although adverse effects of Bt maize on total abundance of nematodes or the abundance of certain feeding types were reported in field studies (Manachini \& Lozzia, 2002; Griffiths et al., 2005), these findings could not be confirmed in other field and glasshouse experiments (Saxena \& Stotzky, 2001; Griffiths et al., 2007).

There are no reports on the effects of Bt maize on soil nematodes in Slovakia, nor in central Europe. In Italy, the nematodes were studied to genus level (Manachini \& Lozzia, 2002) and if there was any species identification, it was done by molecular methods (Griffiths et al., 2005; samples from Denmark and France).

Therefore, the aim of this study was to determine the effects of $\mathrm{Bt}$ maize hybrid cultivation on soil nematode communities in two field trials, as well as to analyse the other factors responsible for the community structure of soil nematodes.

\section{Material and Methods}

Study site

The study was carried out at Borovce (N48 $34.831^{\prime}$ $\mathrm{E} 17^{\circ} 43.302^{\prime}$ ) in western Slovakia in 2012 and 2013. The soil type in the area is loamy luvic chernozem.

\section{Field trials and plot layout}

In 2012, the hybrids included in the experiment were DKC4442YG (Bt maize line MON810) and its near-isogenic line DK440 (FAO 350). DKC3872YG (Bt maize line MON810) and its near-isogenic line DKC3871 (FAO 270) were used in 2013. Each hybrid was sown in 10 repetitions in plots $10 \mathrm{~m} \times 10 \mathrm{~m}$. Each plot was isolated from the other plots by a $5 \mathrm{~m}$ wide strip of barley. Plots were distributed according to a completely randomized design. The agronomic characteristics observed during the two trials on the effect of transgenic insect-resistant maize on the community structure of soil nematodes are reported in Table 1.

Fertilizers used were: i) Eurofertil Plus NP $35^{\circledR}$ (Timac Agro) $15 \%$ nitrogen (N) (5\% as urea and $10 \%$ as ammonium), $20 \%$ phosphorus pentoxide $\left(\mathrm{P}_{2} \mathrm{O}_{5}\right)$ in three forms, $3 \%$ magnesium oxide (MgO), $7.2 \%$ sulphur (S) and $0.5 \%$ zinc (Zn); ii) Granulated urea (diamide of carbonic acid [( $\left.\left.\mathrm{NH}_{2}\right)_{2} \mathrm{CO}\right]$ ) with $46 \% \mathrm{~N}$ (available from many fertiliser companies); and iii) Polidap ${ }^{\circledR}$ (Grupa Azoty ZAK S.A.) includes $18 \% \mathrm{~N}$ in nitrate form and $46 \%$ phosphorus $\left(\mathrm{P}_{2} \mathrm{O}_{5}\right)$ (soluble in neutral ammonium citrate and water) available in mono- and bi-ammonium phosphorus forms. In addition Polidap ${ }^{\circledR}$ includes $5 \%$ sulphur trioxide $\left(\mathrm{SO}_{3}\right)$ soluble in water in sulphate form. As pre-emergence selective herbicide was used Maister ${ }^{\circledR}$ (Bayer Crop Science) (foramsulfurol $300 \mathrm{~g} / \mathrm{kg}$; iodosulfuron-methyl $\mathrm{Na} 10 \mathrm{~g} / \mathrm{kg}$ ) is pre-emergent selective herbicide. Istroekol ${ }^{\circledR}$ (produced and registered by Duslo, a. S., Slovakia) includes rapeseed oil methylester (80\%), was applied in preemergence in a mixture with herbicides. It is an adjuvant used for better effectiveness of pesticides.

\section{Soil sampling, nematode extraction and identification}

For each research variant, ten bulked soil samples (1/plot) were used to investigate nematode communities. A bulked sample consisted of three sub-samples collected at a depth of $15 \mathrm{~cm}$ from the vicinity of plant roots. Weight of each soil sample was about $1 \mathrm{~kg}$. Soil samples were collected during the maize flowering (July 11, 2012 and July 30, 2013). Nematodes were isolated from $50 \mathrm{~g}$ of mixed fresh soil samples using the Baermann's method, fixed in FAA solution and evaluated on permanent glycerine slides (Southey, 1986). All isolated nematodes were identified at species level and juveniles were identified at genus level using a Nikon Eclipse 90i light microscope using original species descriptions and several taxonomic keys: Brzeski (1998), Loof (1999), Siddiqi (2000), Andrássy $(2005,2007,2009)$ and Geraert (2008, 2010).

\section{Data analysis and statistical analysis}

Community indices were calculated for each stand and sampling date in the form of abundance and the diversity index for species (H'spp.) (Shannon \& Weaver, 1949). Nematode species were assigned to different trophic groups according to their feeding habits (Yeates et al., 1993). To assess the nematode communities, the following indices were used: the maturity index (MI), the plant parasitic index (PPI) proposed by Bongers (1990), the ratio of PPI to MI proposed by Bongers and Korthals (1995), the ratio of bacterial feeders to fungal feeders proposed by Wasilewska (1997), the enrichment index (EI) and the structure index (SI) proposed by Ferris et al. (2001).

The composite footprint, enrichment footprint and structure footprint proposed by Ferris (2010), the graphical scheme of cp triangles according De Goede et al., (1993) and the graphical scheme of the soil food web proposed by Ferris et al. (2001) were calculated using the program website "NINJA: An automated calculation system for nematode-based biological monitoring" by Sieriebriennikov et al. (2014).

Data were subjected to analysis of variance and means compared by Tukey's HSD test $(p>0.05)$. Five repetitions from each variant were used in the calculation of difference among four variants. The Statistica programme was used for the calculations shown in Tables 2 and 3. Data were summarised and compared in Excel. Statgraphics Centurion XV was used for assessment of differences between non-Bt and Bt maize.

\section{Results}

Soil, chemical and agricultural characteristic of studied stands No differences were found in average daily soil temperature during the collection of samples in both years of the investigation. Soil moisture on the sampling date was higher in 2012 than in 2013 , and the sum of precipitation in the 30 days before sampling was $25.4 \mathrm{~mm}$ in 2012 and $2.4 \mathrm{~mm}$ in 2013. The average levels of $\mathrm{C}$ (mg/g soil), $\mathrm{N}$ (mg/g soil), the ratio of $\mathrm{C}$ to $\mathrm{N}$ and $\mathrm{pH}$ calculated from samples collected from 10 plots of each variant are reported in Table 1. The maize hybrids, fertilisers, cultivation dates, appli- 
Table 1. Agronomic characteristics observed during the two trials on the effect of transgenic insect-resistant maize on the community structure of soil nematodes

\begin{tabular}{|c|c|c|c|c|}
\hline \multirow{2}{*}{$\begin{array}{l}\text { Year } \\
\text { Hybrid }\end{array}$} & \multicolumn{2}{|l|}{2012} & \multicolumn{2}{|l|}{2013} \\
\hline & $\begin{array}{l}\text { DK440 } \\
\text { (near-isogenic line) } \\
\text { winter wheat }\end{array}$ & $\begin{array}{l}\text { DKC4442YG (Bt } \\
\text { maize line MON810) }\end{array}$ & $\begin{array}{l}\text { DKC3871 (near- } \\
\text { isogenic line) } \\
\text { winter wheat }\end{array}$ & $\begin{array}{l}\text { DKC3872YG (Bt } \\
\text { maize line MON810) }\end{array}$ \\
\hline Fertilisation before sowing & \multicolumn{2}{|c|}{ April 13, Eurofertil Plus NP 35 (300 kg/ha) } & \multicolumn{2}{|c|}{$\begin{array}{l}\text { April 19, Urea (130 kg/ha), Polidap (200 } \\
\mathrm{kg} / \mathrm{ha})\end{array}$} \\
\hline Soil tillage before sowing & \multicolumn{2}{|l|}{ April 17 (cultivator) } & \multicolumn{2}{|c|}{ May 1 (cultivator) } \\
\hline Date of sowing & \multicolumn{2}{|l|}{ April 26} & \multicolumn{2}{|l|}{ May 9} \\
\hline Herbicides & \multicolumn{2}{|c|}{ May 22 (Maister $0.15 \mathrm{l} / \mathrm{ha}+$ Istroekol $2.0 \mathrm{l} / \mathrm{ha}$ ) } & \multicolumn{2}{|c|}{$\begin{array}{l}\text { May } 26 \text { (Maister } 0.15 \text { I/ha + Istroekol } 2.0 \\
\text { I/ha) }\end{array}$} \\
\hline Date of sample collection (flowering) & \multicolumn{2}{|l|}{ July 11} & \multicolumn{2}{|l|}{ July 30} \\
\hline Average daily soil temperature (st60) & \multicolumn{2}{|l|}{20.20} & \multicolumn{2}{|l|}{21.01} \\
\hline Average daily soil temperature (st30) & \multicolumn{2}{|l|}{22.90} & \multicolumn{2}{|l|}{22.62} \\
\hline Average daily soil temperature (st10) & \multicolumn{2}{|l|}{26.07} & \multicolumn{2}{|l|}{24.54} \\
\hline Average daily soil temperature (st5) & \multicolumn{2}{|l|}{26.04} & \multicolumn{2}{|l|}{25.42} \\
\hline Average daily soil temperature (st0) & \multicolumn{2}{|l|}{24.60} & \multicolumn{2}{|l|}{25.70} \\
\hline Daily precipitation (P60) & \multicolumn{2}{|l|}{81.4} & \multicolumn{2}{|l|}{109.8} \\
\hline Daily precipitation (P30) & \multicolumn{2}{|l|}{25.4} & \multicolumn{2}{|l|}{2.4} \\
\hline Daily precipitation (P10) & \multicolumn{2}{|l|}{3.4} & \multicolumn{2}{|l|}{0.0} \\
\hline Daily precipitation (P5) & \multicolumn{2}{|l|}{1.8} & \multicolumn{2}{|l|}{0.0} \\
\hline Daily precipitation (P0) & \multicolumn{2}{|l|}{0.6} & \multicolumn{2}{|l|}{0.6} \\
\hline $\begin{array}{l}\text { Number of days between fertilisation } \\
\text { and soil sampling }\end{array}$ & \multicolumn{2}{|l|}{98} & 101 & \\
\hline $\begin{array}{l}\text { Precipitation between fertilisation and } \\
\text { soil sampling }\end{array}$ & 102.6 & & 145.6 & \\
\hline Soil moisture ${ }^{*}$ & $11.00 b \pm 1.02$ & $10.71 b \pm 1.05$ & $6.81 \mathrm{a} \pm 1.06$ & $6.92 \mathrm{a} \pm 0.75$ \\
\hline $\mathrm{C}(\mathrm{mg} / \mathrm{g})^{*}$ & $12.15 a \pm 1.45$ & $12.34 a \pm 1.41$ & $12.57 \mathrm{a} \pm 1.54$ & $12.20 \mathrm{a} \pm 0.78$ \\
\hline $\mathrm{N}(\mathrm{mg} / \mathrm{g})^{*}$ & $1.40 \mathrm{a} \pm 0.10$ & $1.50 \mathrm{a} \pm 0.16$ & $1.46 a \pm 0.14$ & $1.41 a \pm 0.23$ \\
\hline $\mathrm{C} / \mathrm{N}^{*}$ & $8.67 a \pm 0.67$ & $8.25 a \pm 0.48$ & $8.70 \mathrm{a} \pm 1.66$ & $8.80 \mathrm{a} \pm 0.96$ \\
\hline $\mathrm{pH}^{*}$ & $6.41 \mathrm{a} \pm 0.53$ & $6.17 a \pm 0.44$ & $6.18 \mathrm{a} \pm 0.68$ & $6.16 \mathrm{a} \pm 0.68$ \\
\hline $\begin{array}{l}\text { Percentage of damaged plants by } \\
\text { the European corn borer* }\end{array}$ & $60.00 b \pm 19.22$ & $0.00 \mathrm{a} \pm 0.00$ & $52.33 b \pm 19.14$ & $0.00 \mathrm{a} \pm 0.00$ \\
\hline Yield of maize (t/ha) ${ }^{*}$ & $11.09 b \pm 0.93$ & $11.30 b \pm 0.92$ & $6.08 \mathrm{a} \pm 0.45$ & $6.44 a \pm 0.44$ \\
\hline
\end{tabular}

${ }^{*}$ Means in a row followed by the same letter are not significantly different according to Tukey's HSD test, $P>0.05$

cation of herbicides and climactic conditions were all different. A later sowing date in 2013 was followed by later flowering. Higher soil moisture during flowering in 2012 was followed by significantly higher yield compared to 2013. Year to year, the percentage of plants damaged by the European corn borer was not significantly different in isoline maize plots, and Bt maize plots were not damaged by this pest. Different applications of fertilisers did not result in significant differences in carbon and nitrogen levels in the soil during flowering, and no differences were observed in soil $\mathrm{pH}$. Maize yield was slightly higher in the Bt maize plots, compared to that of the isoline plots although no significant differences were evident (Table 1).

Abundance and species composition of nematode communities Altogether, 39 nematode species belonging to 35 genera were identified in two maize variants. The most prevalent species belonged to the orders Dorylaimida (11) and Tylenchida (11), and the dominant taxa in both variants were Acrobeloides nanus,
Cephalobus persegnis, Aphelenchoides composticola, Aphelenchus avenae, Eudorylaimus carteri and Filenchus vulgaris (Table 2).

The highest average abundance of nematodes was found in the variant with isoline maize in 2012 (465.0 individuals in $50 \mathrm{~g}$ of soil), followed by the Bt maize variant in 2012 (356.8), Bt maize variant in 2013 (182.6) and isoline variant in 2013 (171.9) (Table 2). The differences between the two years were significant, but the differences between $\mathrm{Bt}$ and isoline variant were not significant.

Plant parasite nematodes were represented by ten species: ectoparasites Bitylenchus dubius, Geocenamus sp., Paratylenchus hamatus, Paratylenchus microdorus, Trichodorus primitivus; semi-endoparasites Helicotylenchus digonicus; migratory-endoparasites Pratylenchus neglectus, epidermal/root hair feeders Malenchus exiguus, Psilenchus hilarulus and algal/lichen/moss feeders Tylenchus sp. These species were far less abundant, however, and differences between years or hybrids were not significant (Table 2). 
Table 2. Numbers of nematode in $50 \mathrm{~g}$ of soil Variants include isoline and Bt-line maize plots in 2012 and 2013

\begin{tabular}{|c|c|c|c|c|c|c|c|c|c|c|}
\hline & \multicolumn{2}{|c|}{ Bt2012 } & \multicolumn{2}{|c|}{ Bt2013 } & \multicolumn{2}{|c|}{ Iso2012 } & \multicolumn{2}{|c|}{ Iso2013 } & \multirow[b]{2}{*}{$\mathbf{F}$} & \multirow[b]{2}{*}{$\mathbf{P}$} \\
\hline & $\mathbf{x}$ & SD & $x$ & SD & $x$ & SD & $x$ & SD & & \\
\hline \multicolumn{11}{|l|}{ ARAEOLAIMIDA } \\
\hline Plectus parvus & $0.0 \mathrm{a}$ & 0.00 & $0.3 a$ & 0.95 & $3.7 a$ & 7.2 & $0.1 \mathrm{a}$ & 0.32 & 2.38 & 0.086 \\
\hline Plectus parietinus & $0.4 a$ & 1.14 & $0.3 a$ & 0.68 & $8.8 a$ & 21.88 & $0.0 \mathrm{a}$ & 0.00 & 1.52 & 0.227 \\
\hline Wilsonema sp. & $0.0 \mathrm{a}$ & 0.00 & $0.0 \mathrm{a}$ & 0.00 & $0.0 \mathrm{a}$ & 0.00 & $0.2 a$ & 0.63 & 1.00 & 0.404 \\
\hline \multicolumn{11}{|l|}{ RHABDITIDA } \\
\hline Cephalobus persegnis & $32.6 b$ & 20.43 & $2.6 a$ & 5.34 & $28.4 b$ & 19.31 & $8.6 a$ & 16.49 & 7.90 & 0.000 \\
\hline Heterocephalobus elongatus & $0.0 \mathrm{a}$ & 0.00 & $3.0 \mathrm{~b}$ & 3.62 & $0.0 \mathrm{a}$ & 0.00 & $3.4 b$ & 3.31 & 5.72 & 0.003 \\
\hline Eucephalobus striatus & $25.9 a$ & 32.56 & $0.0 \mathrm{a}$ & 0.00 & $27.7 a$ & 43.66 & $0.0 \mathrm{a}$ & 0.00 & 3.22 & 0.034 \\
\hline Acrobeloides nanus & $127.2 \mathrm{~b}$ & 69.27 & $35.6 a$ & 36.17 & $140.6 b$ & 98.86 & $33.2 \mathrm{a}$ & 17.57 & 8.23 & 0.000 \\
\hline Chiloplacus propinquus & $0.0 \mathrm{a}$ & 0.00 & $18.1 b$ & 21.51 & $0.0 \mathrm{a}$ & 0.00 & $15.0 \mathrm{ab}$ & 15.94 & 5.18 & 0.004 \\
\hline Cervidellus vexilliger & $0.05 a$ & 0.00 & $0.1 \mathrm{a}$ & 0.32 & $0.0 \mathrm{a}$ & 0.00 & $0.1 \mathrm{a}$ & 0.32 & 0.67 & 0.578 \\
\hline Rhabditis spp. & $16.2 \mathrm{a}$ & 16.85 & $1.7 a$ & 2.63 & $13.7 a$ & 23.98 & $0.0 \mathrm{a}$ & 0.00 & 3.13 & 0.038 \\
\hline Panagrolaimus rigidus & $0.0 \mathrm{a}$ & 0.00 & $0.0 \mathrm{a}$ & 0.00 & $0.0 \mathrm{a}$ & 0.00 & $0.3 a$ & 0.95 & 1.00 & 0.404 \\
\hline \multicolumn{11}{|l|}{ APHELENCHIDA } \\
\hline Aphelenchus avenae & $28.0 \mathrm{a}$ & 15.19 & $42.5 a$ & 45.16 & $32.2 a$ & 30.35 & $33.0 \mathrm{a}$ & 16.83 & 0.43 & 0.731 \\
\hline Aphelenchoides composticola & $35.4 b$ & 28.65 & $10.5 a$ & 4.86 & 33.1ab & 26.32 & $20.8 \mathrm{ab}$ & 11.35 & 3.20 & 0.035 \\
\hline Aphelenchoides minimus & $15.6 a$ & 17.12 & $6.5 a$ & 20.56 & $9.9 a$ & 15.48 & $4.8 a$ & 6.97 & 0.90 & 0.451 \\
\hline \multicolumn{11}{|l|}{ TYLENCHIDA } \\
\hline Filenchus vulgaris & $35.1 \mathrm{ab}$ & 19.41 & $28.9 a b$ & 20.79 & $56.0 \mathrm{~b}$ & 45.73 & $19.5 a$ & 21.71 & 2.85 & 0.05 \\
\hline Tylenchus sp. & $0.0 \mathrm{a}$ & 0.00 & $5.2 a$ & 7.21 & $0.6 a$ & 2.2 & $5.4 a$ & 8.61 & 2.56 & 0.070 \\
\hline Malenchus exiguus & $1.0 \mathrm{a}$ & 2.6 & $0.0 \mathrm{a}$ & 0.00 & $12.3 a$ & 27.46 & $0.0 \mathrm{a}$ & 0.00 & 1.89 & 0.149 \\
\hline Ditylenchus intermedius & $0.0 \mathrm{a}$ & 0.00 & $0.0 \mathrm{a}$ & 0.00 & $0.0 \mathrm{a}$ & 0.00 & $0.4 a$ & 0.97 & 1.71 & 0.181 \\
\hline Psilenchus hilarulus & $0.0 \mathrm{a}$ & 0.00 & $0.0 \mathrm{a}$ & 0.00 & $0.0 \mathrm{a}$ & 0.00 & $0.2 a$ & 0.63 & 1.00 & 0.404 \\
\hline Bitylenchus dubius & $2.0 a$ & 3.5 & $0.3 a$ & 0.95 & $13.7 \mathrm{~b}$ & 9.5 & $0.1 \mathrm{a}$ & 0.32 & 18.25 & 0.000 \\
\hline Geocenamus sp. & $0.0 \mathrm{a}$ & 0.00 & $0.1 \mathrm{a}$ & 0.32 & $0.0 \mathrm{a}$ & 0.00 & $0.5 a$ & 1.27 & 1.32 & 0.282 \\
\hline Pratylenchus neglectus & $0.0 \mathrm{a}$ & 0.00 & $0.6 a$ & 0.7 & $0.0 \mathrm{a}$ & 0.00 & $3.3 a$ & 6.9 & 2.64 & 0.064 \\
\hline Helicotylenchus digonicus & $2.8 a$ & 6.35 & $3.1 \mathrm{a}$ & 7.22 & $2.7 a$ & 4.95 & $2.5 a$ & 4.22 & 0.02 & 0.996 \\
\hline Paratylenchus hamatus & $1.1 \mathrm{a}$ & 2.6 & $0.0 \mathrm{a}$ & 0.00 & $1.0 \mathrm{a}$ & 2.16 & $0.7 a$ & 1.34 & 0.87 & 0.468 \\
\hline Paratylenchus microdorus & $2.1 \mathrm{a}$ & 4.55 & $0.8 a$ & 1.4 & $5.1 a$ & 6.96 & $0.5 a$ & 1.27 & 2.41 & 0.083 \\
\hline \multicolumn{11}{|l|}{ ALAIMIDA } \\
\hline Alaimus primitivus & $0.0 \mathrm{a}$ & 0.00 & $0.0 \mathrm{a}$ & 0.00 & $5.2 b$ & 5.05 & $0.2 \mathrm{a}$ & 0.42 & 10.16 & 0.000 \\
\hline \multicolumn{11}{|l|}{ DIPHTHEROPHORIDA } \\
\hline Trichodorus primitivus & $0.0 \mathrm{a}$ & 0.00 & $0.2 a$ & 0.42 & $0.0 \mathrm{a}$ & 0.00 & $0.8 a$ & 1.55 & 2.56 & 0.070 \\
\hline \multicolumn{11}{|l|}{ MONONCHIDA } \\
\hline Mylonchulus sigmaturus & $1.4 a b$ & 2.5 & $0.0 \mathrm{a}$ & 0.00 & $4.9 \mathrm{~b}$ & 6.3 & $0.0 \mathrm{a}$ & 0.00 & 4.62 & 0.008 \\
\hline Iotonchus sp. & $0.0 \mathrm{a}$ & 0.00 & $0.2 \mathrm{a}$ & 0.42 & $0.8 a$ & 2.47 & $0.5 a$ & 0.85 & 0.67 & 0.576 \\
\hline \multicolumn{11}{|l|}{ DORYLAIMIDA } \\
\hline Mesodorylaimus bastiani & $2.6 a$ & 3.74 & $0.0 \mathrm{a}$ & 0.00 & $3.9 a$ & 5.9 & $0.1 \mathrm{a}$ & 0.32 & 2.99 & 0.043 \\
\hline Discolaimus texanus & $6.3 a$ & 19.92 & $0.5 a$ & 1.58 & $0.3 a$ & 1.1 & $0.8 \mathrm{a}$ & 1.93 & 0.82 & 0.489 \\
\hline
\end{tabular}




\begin{tabular}{lcccccccccc} 
Crassolabium ettersbergense & $0.6 \mathrm{ab}$ & 1.83 & $0.0 \mathrm{a}$ & 0.00 & $5.1 \mathrm{~b}$ & 7.45 & $0.4 \mathrm{ab}$ & 1.27 & 3.76 & 0.019 \\
Eudorylaimus carteri & $10.1 \mathrm{a}$ & 7.11 & $20.0 \mathrm{a}$ & 10.57 & $23.6 \mathrm{a}$ & 14.91 & $13.9 \mathrm{a}$ & 11.06 & 2.88 & 0.049 \\
Eudorylaimus sp. 1 juv. & $0.0 \mathrm{a}$ & 0.00 & $0.6 \mathrm{a}$ & 1.9 & $1.7 \mathrm{a}$ & 5.5 & $1.1 \mathrm{a}$ & 2.85 & 0.52 & 0.671 \\
Eudorylaimus sp. 2 juv. & $9.8 \mathrm{a}$ & 7.4 & $16.3 \mathrm{a}$ & 9.82 & $11.5 \mathrm{a}$ & 6.58 & $10.8 \mathrm{a}$ & 10.43 & 1.11 & 0.358 \\
Ecumenicus monohystera & $0.0 \mathrm{a}$ & 0.00 & $0.0 \mathrm{a}$ & 0.00 & $0.0 \mathrm{a}$ & 0.00 & $0.7 \mathrm{a}$ & 1.58 & 2.00 & 0.132 \\
Aporcelaimellus obtusicaudatus & $0.0 \mathrm{a}$ & 0.00 & $1.1 \mathrm{a}$ & 1.85 & $0.0 \mathrm{a}$ & 0.00 & $0.1 \mathrm{a}$ & 0.32 & 3.25 & 0.033 \\
Enchodelus macrodorus & $0.0 \mathrm{a}$ & 0.00 & $0.2 \mathrm{a}$ & 0.42 & $0.0 \mathrm{a}$ & 0.00 & $0.0 \mathrm{a}$ & 0.00 & 2.25 & 0.099 \\
Dorylaimoides micoletzkyi & $0.0 \mathrm{a}$ & 0.00 & $0.0 \mathrm{a}$ & 0.00 & $0.0 \mathrm{a}$ & 0.00 & $0.6 \mathrm{a}$ & 1.27 & 2.25 & 0.099 \\
Doryllium zeelandicum & $10.8 \mathrm{a}$ & 7.95 & $0.2 \mathrm{a}$ & 0.63 & $32.1 \mathrm{~b}$ & 25.3 & $1.8 \mathrm{a}$ & 4.8 & 12.23 & 0.000 \\
\hline Abundance of nematodes & $356.8 \mathrm{~b}$ & 161.4 & $182.6 \mathrm{a}$ & 74.06 & $465.0 \mathrm{~b}$ & 192.4 & $171.9 \mathrm{a}$ & 67.42 & 11.03 & 0.000 \\
\hline Each variant include 10 replicates. Means in rows followed by the same letter are not significantly different according to Tukey's HSD test; P $\mathrm{P} \leq .05$. ANOVA was not \\
$\quad$ performed in the rows without letters because of low numbers of particular species. Identified species were classified according Andrássy (2005, 2007, 2009)
\end{tabular}

Representation of nematode trophic groups

Bacterial feeders and fungal feeders in both hybrids and years (Table 3) were the dominant trophic groups. In both cases, the year had an evident influence on both nematode group abundances. The abundance of fungal feeders in 2013 achieved $28.67 \%$ or $39.10 \%$ of all nematodes dependent on the hybrid grown. In 2012 the percentage of fungal feeders was $24.90 \%$ (Bt maize) and $22.6 \%$ (isoline maize). In 2012 the highest percentage of bacterial feeders was found in the soil from the $\mathrm{Bt}$ maize variant $(56.1 \%)$, followed by the isoline variant $(48.4 \%)$. Both variants in 2013 had significantly lower percentage of bacterial feeders $(34.7 \%$ and $33.2 \%$ respectively) compared to those evaluated in 2012. Table 3 also shows that percentage of predators and omnivores was not clearly influenced by conditions of year or hybrid. Root-fungal feeders and plant parasite communities were not significantly influenced by year or hybrid.

\section{Ecological evaluation of nematode communities}

The ecological evaluation of nematode communities through the calculation of the maturity index, plant parasitic index, enrichment index and structure index did not confirm any clear influence of the year or hybrid on nematode communities (Table 3).

Figure 1 confirms that nematode fauna from each of the ten replicates of the four variants of this study were "found" in the right lover corner of the diagram (low stability, high stress). Just two replicates of soil samples collected in isoline maize plots in 2012 demonstrated a difference from this trend; however, the other eight replicates did not confirm it.

Calculations of the structure and enrichment conditions of the soil food web for isoline and Bt-line maize plots in 2012 and 2013 were found in the quadrant at the bottom left of the diagram (Fig. 2). This quadrant represents a degraded environment with a high C:N ratio and high levels of fungal feeders. No distinctive differences among studied variants were observed.

Table 3. Ecological evaluation of nematode community structure in isoline and Bt-line maize plots in 2012 and 2013

\begin{tabular}{|c|c|c|c|c|c|c|c|c|c|c|}
\hline & \multicolumn{2}{|c|}{ Bt2012 } & \multicolumn{2}{|c|}{ Bt2013 } & \multicolumn{2}{|c|}{ Iso2012 } & \multicolumn{2}{|c|}{ Iso2013 } & \multirow[b]{2}{*}{$\mathbf{F}$} & \multirow[b]{2}{*}{$\mathbf{P}$} \\
\hline & $\mathbf{x}$ & sd & $\mathbf{x}$ & sd & $\mathbf{x}$ & sd & $\mathbf{x}$ & sd & & \\
\hline Diversity index for species & $1.99 a b$ & 0.2 & $1.81 \mathrm{a}$ & 0.31 & $2.14 b$ & 0.16 & $2.02 \mathrm{ab}$ & 0.22 & 3.38 & 0.029 \\
\hline Bacterial feeders & $56.1 \mathrm{~b}$ & 6.49 & $33.2 \mathrm{a}$ & 14.28 & $48.4 b$ & 10 & $34.71 \mathrm{a}$ & 7.15 & 12.27 & 0.000 \\
\hline Fungal feeders & $24.90 a$ & 9.42 & $28.67 a$ & 21.38 & $22.6 a$ & 9.56 & $39.10 a$ & 12.84 & 2.66 & 0.063 \\
\hline Omnivores & $5.2 a$ & 3.77 & $12.62 b$ & 5.93 & $6.9 a$ & 1.91 & $8.91 \mathrm{ab}$ & 4.91 & 5.28 & 0.004 \\
\hline Predators & $0.6 \mathrm{ab}$ & 1.08 & $0.11 \mathrm{a}$ & 0.24 & $1.2 b$ & 1.23 & $0.23 a b$ & 0.4 & 3.33 & 0.030 \\
\hline Root-fungal feeders & $10.7 a$ & 6.09 & $22.78 a$ & 18.21 & $15.9 a$ & 10.96 & $12.1 \mathrm{a}$ & 9.6 & 2.01 & 0.129 \\
\hline Plant parasites & $2.5 a$ & 2.27 & $2.62 a$ & 3.5 & $5.0 a$ & 2.79 & $4.96 a$ & 4.04 & 1.88 & 0.150 \\
\hline Maturity index (MI) & $2.22 \mathrm{a}$ & 0.16 & $2.49 b$ & 0.27 & $2.44 a b$ & 0.09 & $2.36 \mathrm{ab}$ & 0.18 & 4.16 & 0.013 \\
\hline Plant parasitic index (PPI) & $2.04 a$ & 0.09 & $2.06 \mathrm{a}$ & 0.12 & $2.03 a$ & 0.04 & $2.19 a$ & 0.33 & 1.58 & 0.211 \\
\hline Ratio of PPI to MI & $0.92 a$ & 0.08 & $0.84 a$ & 0.11 & $0.83 a$ & 0.04 & $0.94 a$ & 0.18 & 2.27 & 0.097 \\
\hline Bacterial/Fungal feeders & $2.71 \mathrm{a}$ & 1.47 & $2.05 a$ & 1.74 & $2.84 a$ & 2.07 & $1.02 \mathrm{a}$ & 0.48 & 2.83 & 0.052 \\
\hline Enrichment index & $12.78 \mathrm{a}$ & 7.86 & $40.8 a b$ & 32.56 & 17.6ab & 17.46 & $52.91 b$ & 15.47 & 8.70 & 0.000 \\
\hline Structure index & $1.83 a$ & 1.32 & $10.0 \mathrm{ab}$ & 7.49 & $12.47 \mathrm{~b}$ & 15.35 & $3.48 a b$ & 2.92 & 3.46 & 0.026 \\
\hline
\end{tabular}

Each variant included 10 replicates. Means in rows followed by the same letter are not significantly different according to Tukey's HSD test; P $\leq 0.05$ 


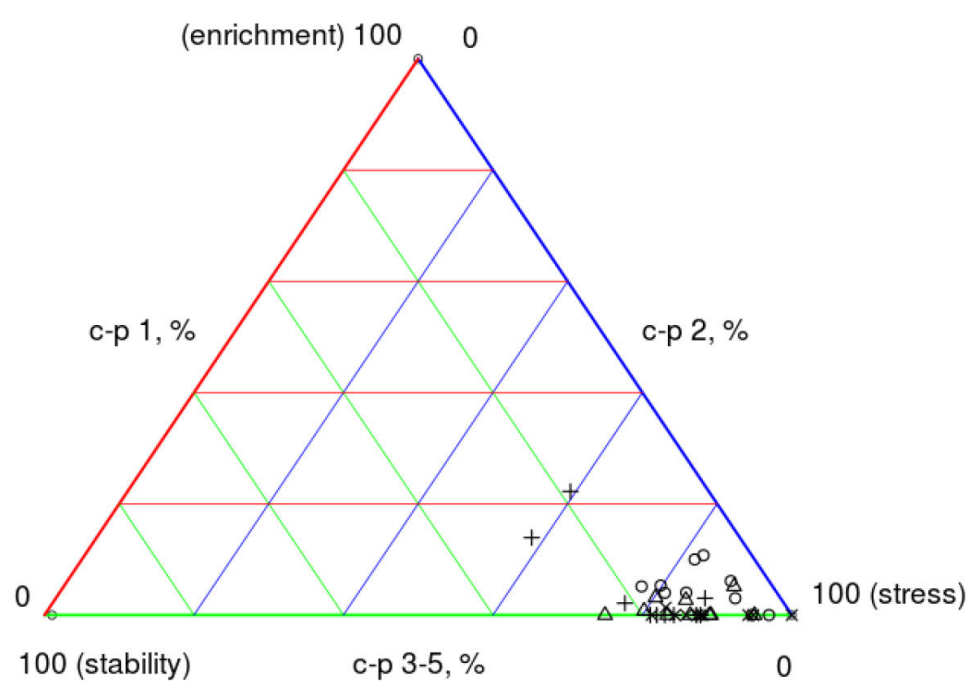

Fig. 1. Proportional representation of cp-1, cp-2 and cp-3 groups of the nematode fauna, data calculated using NINJA: An automated calculation system for nematode-based biological monitoring (Sieriebriennikov et al. 2014). Variants included isoline (ISO) and Bt-line (BT) maize plots in 2012 and 2013. Each variant included 10 replicates.

The metabolic footprint indicates at difference between the isoline maize variant and Bt maize variant in 2012, but this difference was not evident in 2013 (Fig. 3).

\section{Discussion}

According to Griffiths et al. (2012), nematode abundance in the soil depends on the method of cultivation, sampling time during the season and the year of study. Fertiliser treatment may affect nematode densities (Okada \& Harada, 2007), but we do not think that the year to year application of fertiliser in our study was different enough to make any significant difference. A significant higher abundance of nematodes in 2012 compared to 2013 was observed in our study and it was correlated to soil moisture. The dry conditions in 2013 probably negatively influenced the abundance of nematodes in the soil, especially for the increase of bacterial feeders in soils with higher moisture. In fact in 2012, when soil moisture was higher, a higher percentage of bacterial feeders was found compared to 2013. The abundance of bacteria is positively influenced by soil moisture. In the rain plots (one rain

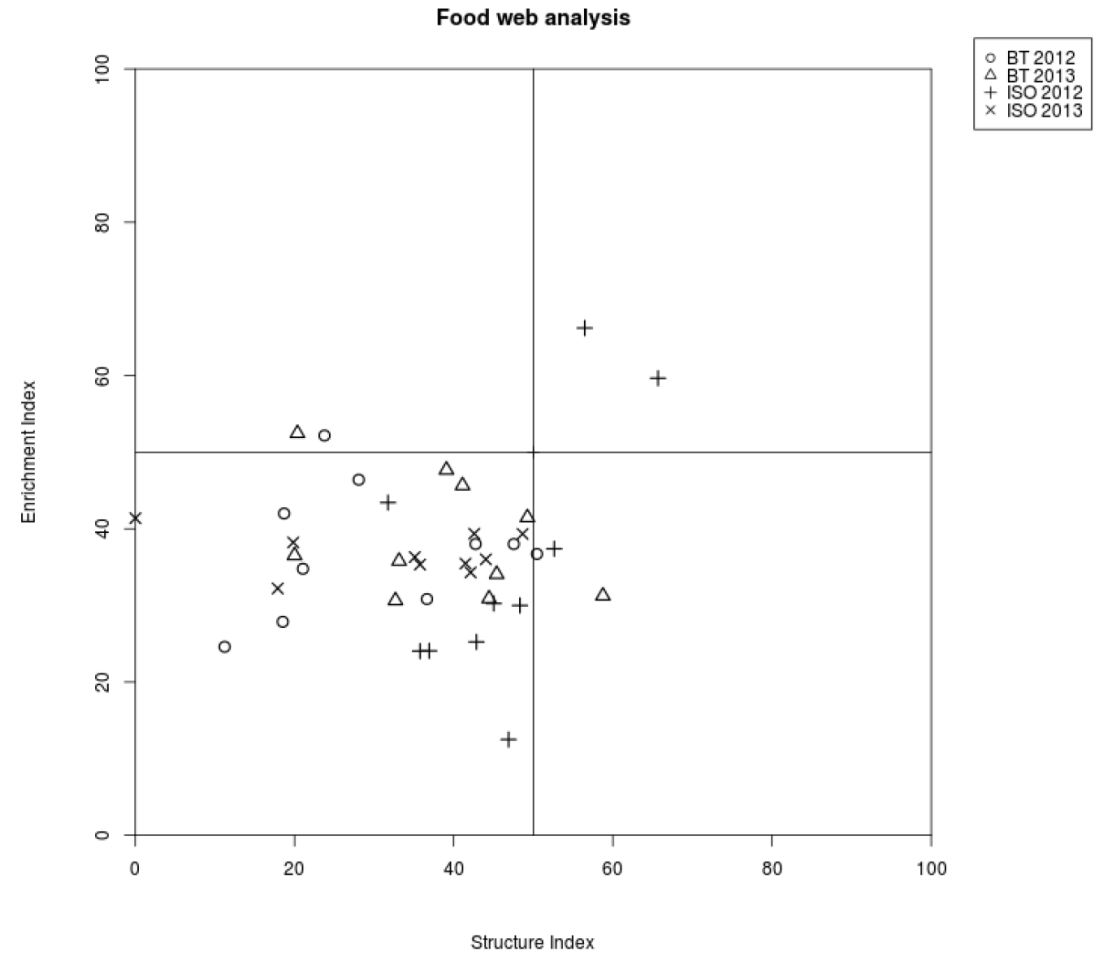

Fig. 2. Faunal profile representing the structure and enrichment conditions of the soil food web for isoline (ISO) and Bt-line (BT) maize plots in 2012 and 2013 at Borovce, Slovakia. Each variant included 10 replicates. Data calculated using NINJA: An automated calculation system for nematode-based biological monitoring (Sieriebriennikov et al. 2014). 


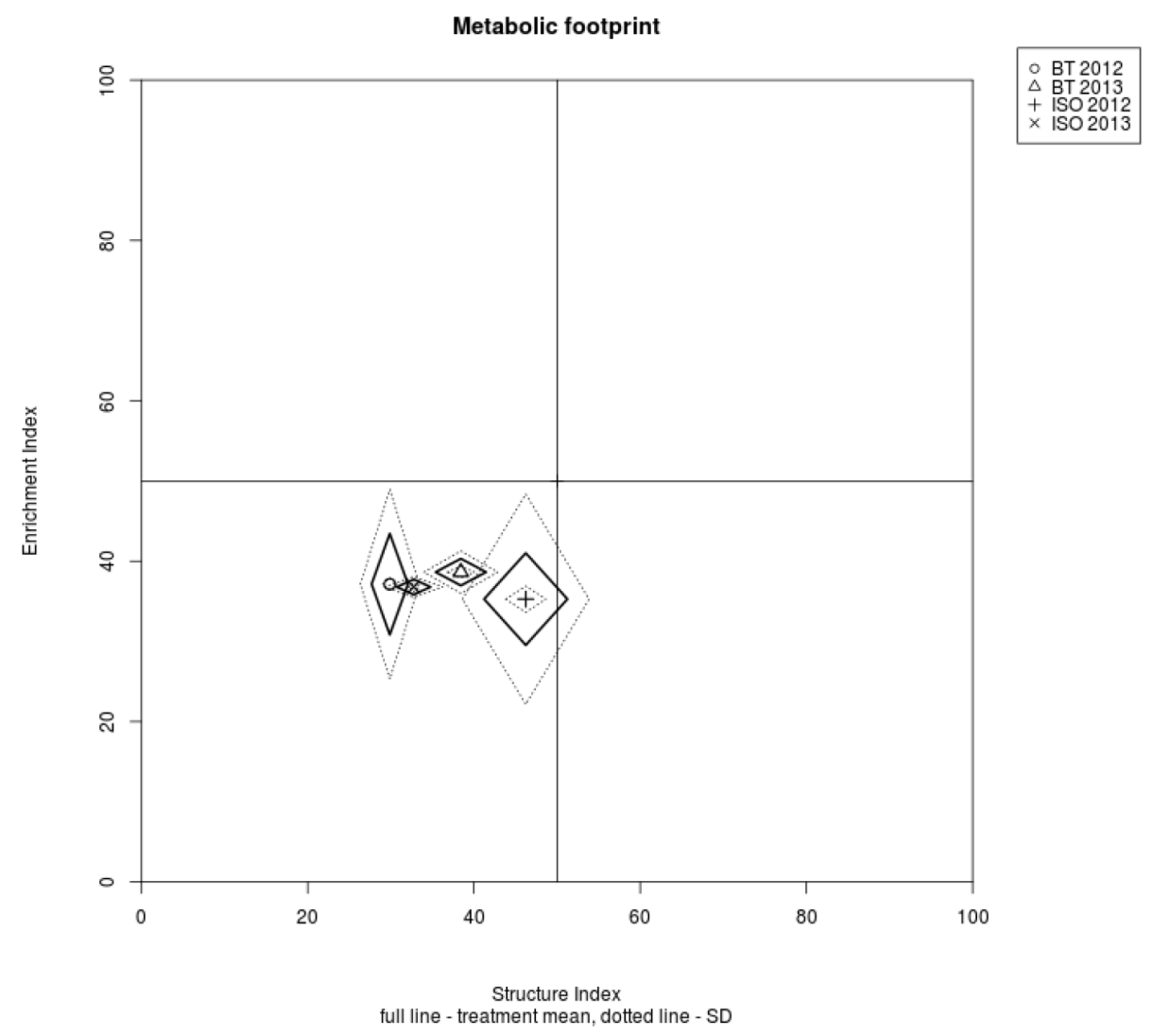

Fig. 3. Metabolic footprint of nematodes in the soil food web for isoline (ISO) and Bt-line (BT) maize plots in 2012 and 2013 at Borovce, Slovakia. Each variant included 10 replicates. Data calculated using NINJA: An automated calculation system for nematode-based biological monitoring (Sieriebriennikov et al. 2014).

and no rain later on), bacterial numbers doubled within three days and declined during the following period of drought. In the irrigated plots (irrigation every 10 days), bacterial numbers increased by $50 \%$ and then remained constant over the duration of the study (Schnürer et al., 1986). In 2013, a higher proportion of fungal feeders was found in soil samples. The association of soil communities with soil moisture was studied in a vineyard under two frequencies of deficit irrigation. An increased fungal biomass was associated with a low-frequency irrigation regime, whereas all other organisms were more abundant in the soil kept more constantly moist (Holland et al., 2013). In both investigated years, the relative moisture of the soil was relatively low. This is likely the reason why the ratio of bacterial/fungal feeders was not significantly different from year to the other year. Small differences in the soil humidity probably would not change abundance of nematodes. Similarly, in the Chihuahuan desert, water $(25 \mathrm{~mm}$ per month or $6 \mathrm{~mm}$ per week) had no significant effect $(P<0.05)$ on annual mean densities of total nematodes, fungivores, bacterivores or omnivore predators in the soil (Freckman et al., 1987). The dominant taxa in both variants were Acrobeloides nanus, Cephalobus persegnis, Aphelenchoides composticola, Aphelenchus avenae, Eudorylaimus carteri and Filenchus vulgaris. From these six species, only bacterial feeders $(A$. nanus and $C$. persegnis) showed any significant reaction to climatic conditions from year to year, and both were responsible for different levels of nematode abundance in both studied years. Both species are common in soils with various physical and chemical properties and they constitute a large part of soil nematode communities in extremely different habitats (Sultanalieva, 1986; Doroszuk et al., 2006; Khan et al., 2013).

Plant parasitic nematodes were represented by ten species, but differences in the abundance of ecto- and endoparasitic species were not clearly confirmed. Jones et al. (1969) noted that whereas ectoparasitic nematodes live entirely in the soil, endoparasitic ones soon leave it to enter in plant roots, where they are unaffected by soil moisture.

In the proportional representation of $\mathrm{cp}-1, \mathrm{cp}-2$ and $\mathrm{cp}-3-5$ functional groups of nematode communities (Figure 1, c-p triangle) all ten replicates of the four variants in this study were set in the bottom right corner of the diagram which is an indication for some environmental stress. Furthermore, $c-p$ triangle shows a very slight influence of the year on the proportional representation of the $\mathrm{cp}-1$, $\mathrm{cp}-2$ and $\mathrm{cp}-3-5$ groups of nematode fauna, but the influence of $\mathrm{Bt}$ hybrids is disputable. In 2012, four isoline replicates showed higher levels of "enrichment" with relatively high variability, but eight replicates of Bt-line variants showed a similar trend with a lower variability. Figure 2 (food web analysis) also shows greater similarity among replicates in the Bt-line variant. In 2013, only two replicates showed a slightly higher enrichment level (Figure 1), the trend was confirmed in Figure 2. This situation was probably caused by the hybrid properties. It seems that isoline hybrids were probably less stable in the face of insect pests compared to Bt-line hybrids, which could influence nematode population. Root-feeding nematodes can positively or negatively affect shoot herbivorous 
insects, and vice versa. The potential mechanisms for these interactions include systemic induced plant defence, interference with the translocation and dynamics of locally induced secondary metabolites and reallocation of plant nutritional reserves (Wondafrash et al., 2013). Although, while the attack of European corn borer larvae may have caused some changes in the nematode communities in the soil, we could not confirm this effect and recommend it as a goal for future study.

Figure 2 also shows that the experiment was performed in a locality defined as degraded, and with high C:N (Ferris et al., 2001). Similarly, in northeast China, the faunal profiles showed that soil food webs in the fallow fields and woodland were structured whereas, those in the paddy and maize fields were stressed (Ou et al., 2005).

The situation depicted in Figures 1 and 2 is better explained in Figure 3. In 2012, the difference between the "metabolic footprint" of the Bt-line and isoline was found to be a cause for concern (Ferris \& Bongers, 2009; Ferris, 2010; Sieriebriennikov et al., 2014). Nematode populations extracted from plots with isolines showed a higher structure index compared to populations collected in Bt-maize plots, indicating a difference between the hybrids used. In 2013, with low variability among replicates, the opposite trend was found. Thus, results from 2013 did not confirm that Bt maize has some impact on the nematode community. We support the idea that the toxin released into the soil from $\mathrm{Bt}$ maize has no significant effects on nematodes (Saxena \& Stotzky, 2001) even though toxin released from root exudates of Bt maize is able to persist in rhizosphere soil for at least 180 days (Saxena \& Stotzky, 2002).

\section{Conclusions}

Soil nematode communities are not influenced by the cultivation of Bt maize hybrids.

Fertiliser treatment may affect nematode densities, but the minor differences in their application that are typical in agronomic practice do not significantly influence soil nematode populations.

Soil moisture is an important factor influencing soil nematode community.

Attack of the European corn borer larvae may cause some changes in soil nematode communities.

Different maize hybrids may influence nematode communities in a specific year, but there are many other, more important factors that are more influential.

\section{Acknowledgements}

This research was supported by the EU project AMIGA, "Assessing and Monitoring the Impacts of Genetically Modified Plants on Agro-ecosystems", funded by the FP7.

\section{References}

AL-DeEb, M.A., WILDE, G.E., BLAIR, J.M., TODD, T.C. (2003): Effect of $B t$ corn for corn rootworm control on nontarget soil microarthropods and nematodes. Environ. Entomol., 32(4): 859 - 865. DOI: 10.1603/0046-225X-32.4.859

ANDRÁSSY, I. (2005): Free-living nematodes of Hungary Nema- toda errantia, Volume I. Budapest, Hungarian Natural History Museum and Systematic Zoology Research Group of the Hungarian Academy of Sciences, $518 \mathrm{pp}$.

ANDRÁSSY, I. (2007): Free-living nematodes of Hungary Nematoda errantia, Volume II. Budapest, Hungarian Natural History Museum and Systematic Zoology Research Group of the Hungarian Academy of Sciences, $496 \mathrm{pp}$.

ANDRÁSSY, I. (2009): Free-living nematodes of Hungary Nematoda errantia, Volume III. Budapest, Hungarian Natural History Museum and Systematic Zoology Research Group of the Hungarian Academy of Sciences, $608 \mathrm{pp}$.

BAKONYI, G., NAgY, P., KovÁcs-LÁng, E., KovÁcS, E., BarabÁS, S., RÉPÁSI, V., SERES, A. (2007): Soil nematode community structure as affected by temperature and moisture in a temperate semiarid shrubland. Appl. Soil Ecol., 37(1 - 2): 31 - 40. DOI: 10.1016/j.apsoil.2007.03.008

BONGERS, T. (1990): The maturity index: an ecological measure of environmental disturbance based on nematode species composition. Oecologia, 83(1): $14-19$

BONGERS, T., KORTHALS, G. (1995): The behaviour of MI and PPI under enriched conditions. Nematologica, 41: 286

BRZESKI, M.W. (1998): Nematodes of Tylenchida in Poland and temperate Europe. Museum of Institute of Zoology, Polish Academy of Sciences, Warszawa, 397 pp.

De Goede, R.G.M., Bongers, T., ETTEMA, C.H. (1993): Graphical presentation and interpretation of nematode community structure, c-p triangles. Meded. Fac. Landbouww. Univ. Gent, 58: 743 - 750

DoRoszuK, A., WoJeWOdzIC, M.W., KAMmENGA, J.E. (2006): Rapid adaptive divergence of life-history traits in response to abiotic stress within a natural population of a parthenogenetic nematode. Proc. Biol. Sci., 273(1601): 2611 - 2618. DOI: 10.1098/rspb.2006.360

DuPONT, S.T., FERRIS, H., VAN HORN, M. (2009): Effects of cover crop quality and quantity on nematode-based soil food webs and nutrient cycling. Appl. Soil Ecol., 41(2): 157 - 167. DOI: 10.1016/j.apsoil.2008.10.004

FERRIS, H. (2010): Form and function: Metabolic footprints of nematodes in the soil food web. Eur. J. Soil Biol., 46(2): 97 - 104. DOI: 10.1016/j.ejsobi.2010.01.003

FERRIS, H., BONGERS, T. (2006): Nematode indicators of organic enrichment. J. Nematol. 38(1): 3 - 12

FERRIS, H., BONGERS, T. (2009): Indices for analysis of nematode assemblages. In: M. Wilson, M., Kakouli-Duarte, T. (Eds) Nematodes as Environmental Bioindicators. Wallingford. CABI, pp. 124 $-145$

FerRIS, H., Bongers, T., De Goede, R.G.M. (2001) A framework for soil food web diagnostics: extension of the nematode faunal analysis concept. Appl. Soil Ecol., 18(1): 13 - 29. DOI: 10.1016/S0929-1393(01)00152-4

FRECKMAN, D.W., WHITFORD, W.G., STEINBERGER, Y. (1987): Effect of irrigation on nematode population dynamics and activity in desert soils. Biol. Fertil. Soils, 3(1-2): $3-10$

GERAERT, E. (2008): The Tylenchidae of the world. Identification of the family Tylenchidae (Nematoda). Academia Press, Gent, $540 \mathrm{pp}$.

GERAERT, E. (2010): The Criconematidae of the world. Identification of the family Criconematidae (Nematoda). Academia Press, Gent, $615 \mathrm{pp}$. 
GriffithS, B.S., CAUL, S., ThOMPSON, J., BIRCH, A.N.E., Scrimgeour, C., Andersen, M.N., Cortet, J., Messéan, A., SAUSSE, C., LACROIX, B., KROGH, P.H. (2005): A comparison of soil microbial community structure, protozoa and nematodes in field plots of conventional and genetically modified maize expressing the Bacillus thuringiensis CrylAb toxin. Plant Soil, 275(1 - 2): 135 - 146. DOI: $10.1007 / \mathrm{s} 11104-005-1093-2$

GRIFFITHS, B.S., CAUL, S., THOMPSON, J., BIRCH, A.N.E., Scrimgeour, C., Cortet, J., Foggo, A., Hackett, C.A., Krogh, P.H. (2006): Soil microbial and faunal community responses to $\mathrm{Bt}$ maize and insecticide in two soils. J. Environ. Qual., 35(3): 734 741. DOI: 10.2134/jeq2005.0344

GRIFFITHS, B.S., DANIELL, T.J., DonN, S., NeILSO, R. (2012): Bioindication potential of using molecular characterisation of the nematode community: Response to soil tillage. European J. of Siol Biology., 49: 92 - 97. DOI: 10.1016/j.ejsobi.2011.09.002

GRIFFITHS, B.S., HECKMANN, L.H., CAUL, S., THOMPSON, J., SCRIMgEOUR, C., KROGH, P.H. (2007): Varietal effects of eight paired lines of transgenic Bt maize and near-isogenic non-Bt maize on soil microbial and nematode community structure. Plant Biotech. J., 5: $60-68$

Holland, T.C., Reynolds, A.G., Bowen, P.A., Bogdanoff, C.P., MARCINIAK, M., BROWN, R.B., HART, M.M. (2013): The response of soil biota to water availability in vineyards. Pedobiologia., 56(1): 9 - 14. DOI: 10.1016/j.pedobi.2012.08.004

Höss, S., Menze, R., Gessle, F., NGuyen, H.T., JeHLE, J.A., TRAUNSPURG, W. (2013): Effects of insecticidal crystal proteins (Cry proteins) produced by genetically modified maize (Bt maize) on the nematode Caenorhabditis elegans. Environ. Pollut., 178: 147 - 151. DOI: 10.1016/j.ecoenv.2007.10.017

Höss, S., Nguyen, H.T., Menzel. R., Pagel-Wieder. S., Miethling-Graf, R., Tebbe, C.C., Jehl,e J.A., Traunspurger, W. (2011): Assessing the risk posed to free-living soil nematodes by a genetically modified maize expressing the insecticidal Cry3Bb1 protein. Sci. Total. Environ., 409(13): 2674 - 2684. DOI: 10.1016/j.scitotenv.2011.03.041

JONES, F.G.W., LARBEY, D.W., PARROTT, D.M. (1969):_The influence of soil structure and moisture on nematodes, especially xiphinema, longidorus, trichodorus and heterodera spp. Soil Biol Biochem., 1(2): 153 - 165. DOI: 10.1016/0038-0717(69)90006-6 Karuri, H., Amata, R., Amugune, N., Waturu, C. (2013): Effect of Bt cotton expressing Cry1Ac and Cry2Ab2 protein on soil nematode community assemblages in Mwea, Kenya. J. Anim. Plant Sci., 19(1): $2864-2879$

Khan, J., Khan, M.A., Gul, R., Alı, S., AhMed, M. (2013): Geographical distribution of nematodes associated with fresh water plants in Khyber-Pakhtunkhwa. Scholarly J. Agric. Sci., 3(11): $497-505$

Loof, P.A.A. (1999): Nematoda: Adenophorea (Dorylaimida). Heidelberg, Berlin, Spektrum Akademischer Verlag, 264 pp.

MANACHINI, B., LOZZIA, G. (2002): First investigations into the effects of Bt corn crop on Nematode fauna. Boll. Zool. agr. Bachic. Ser II., 34(1): $85-96$
NEHER, D.A. (2001): Role of nematodes in soil health and their use as indicators. J. Nematol., 33(4): $161-168$

NeHER, D.A., MuthumBI, A.W.N., DivelY, G.P. (2014): Impact of coleopteran-active Bt corn on non-target nematode communities in soil and decomposing corn roots. Soil Biol. Biochem., 76: 127 - 135. DOI: 10.1016/j.soilbio.2014.05.019

OU, W., LIANG, W., JIANG, Z., LI, Q., WEN, D. (2005): Vertical distribution of soil nematodes under different land use types in an aquic brown soil. Pedobiologia, 49: 139 - 148

OKADA, H., HARADA, H. (2007): Effects of tillage and fertilizer on nematode communities in a Japanese soybean field. Appl. Soil Ecol., 35(3): 582 - 598. DOI: 10.1016/j.apsoil.2006.09.008

SAXENA, D., StOTZKY, G. (2001): Bacillus thuringiensis (Bt) toxin released from root exudates and biomass of Bt corn has no apparent effect on earthworms, nematodes, protozoa, bacteria, and fungi in soil. Soil Biol. Biochem., 33: 1225 - 1230

SAXENA, D., STOTZKY, G. (2002): Bt toxin is not taken up from soil or hydroponic culture by corn, carrot, radish, or turnip. Plant Soil, 239: $165-172$

SCHNÜRER, J., ClARHOLM, M., BOSTRÖM, S., ROSSWALL, T. (1986): Effects of moisture on soil microorganisms and nematodes: $A$ field experiment. Microb. Ecol., 12: $217-230$

SHANNON, C.E., WEAVER, W. (1949): The mathematical theory of communication. Urbana, University of Illinois Press. 117 pp.

SIDDIQI, M.R. (2000): Tylenchida, Parasites of Plants and Insects. 2nd edition, CABI Publishing, 833 pp.

SieriebrienNiKov, B., FerRIS, H., De GoEde, R.G.M. (2014): Ninja: An automated calculation system for nematode-based biological monitoring. Eur. J. Soil Biol., 61: 90 - 93. DOI: 10.1016/j.ejsobi.2014.02.004

SULTANALIEVA, G.B. (1986): Remove from marked records free living and plant parasitic nematodes in the principal soil types of the Issyk-Kul' basin, In: Svobodnozhivushchie i paraziticheskie skoletsidy fauny Kirgizii. llim, Frunze, pp. $57-67$

SUN, X., ZHANG, X., ZHANG, S., DAI, G., HAN, S., LIANG, W. (2013): Soil nematode responses to increases in nitrogen deposition and precipitation in a temperate forest. Plos One, 8: e82468. DOl: 10.1371/journal.pone.0082468

WASILEWSKA, L. (1997): Soil invertebrates as bioindicators, with special reference to soil-inhabiting nematodes. Russ. J. Nematol., 5(2): $113-126$

Wei, J.Z., Hale, K., Carta, L., Platzer, E., Wong, C., Fang, S.C., AROIAN, R.V. (2003): Bacillus thuringiensis crystal proteins that target nematodes. Proc. Natl. Acad. Sci., 100(5): 2760 - 2765. DOI: 10.1073/pnas.0538072100

WONDAFrash, M., Van DaM, N.M., TYTGat, T.O. (2013): Plant systemic induced responses mediate interactions between root parasitic nematodes and aboveground herbivorous insects. Front. Plant Sci., 4: 87. DOI: 10.3389/fpls.2013.00087

YEATES, G.W., BONGERS, T., DE GOEdE, R.G.M., FRECKMAN, D.W., GEORGIEVA, S.S. (1993): Feeding habits in soil nematode families and genera - an outline for soil ecologists. J. Nematol., 25(3): $315-331$ 